\title{
Chemical Characteristics and Assessment of Drinking Water Quality of Groundwater in Upper Wainganga River Basin, Gondia District, Maharashtra, India
}

\author{
M. M. $\operatorname{Ali}^{1^{*}}$, N. T. Khaty ${ }^{2}$, Devendra Pandey ${ }^{3}$ and M. D. Choudhary ${ }^{4}$ \\ ${ }^{1}$ Department of Applied Chemistry, Manoharbhai Patel Institute of Engineering \& Technology, Gondia, \\ Maharashtra, India \\ ${ }^{2}$ Department of Applied Chemistry, Priyadarshini College of Engineering, Nagpur, Maharashtra, India \\ ${ }^{3}$ Department of Civil Engineering, Manoharbhai Patel Institute of Engineering \& Technology, Gondia, \\ Maharashtra, India \\ ${ }^{4}$ Department of Applied Chemistry, B. D. College of Engineering, Sevagram, Wardha, Maharashtra, India \\ Email: mmaligondia@yahoo.co.in
}

\begin{abstract}
In the present paper, the assessment of Groundwater of upper Wainganga River Basin, Gondia District, Maharashtra, India has been done. The rock-water interaction under alkaline condition is the main mechanism in activating mineral dissociation and dissolution, causing the release of $\mathrm{Ca} 2+, \mathrm{Na}+, \mathrm{HCO} 3-, \mathrm{SO} 42-$ and F- ions into the groundwater of study area. The ionic relations also suggest that the higher concentrations of $\mathrm{Na}+$ and $\mathrm{Cl}$ - ions are the results of ion exchange and evaporation. The correlations between ions suggest that anthropogenic sources are also responsible for higher concentration of $\mathrm{Ca} 2+, \mathrm{Na}+, \mathrm{HCO} 3-, \mathrm{SO} 42-$ and NO3- ions. The high bicarbonate, arid climate of the region and the granitic rocks accelerates the dissolution of F- bearing minerals and leads to high fluoride content. The study reveals that majority of groundwater samples are not suitable for drinking.
\end{abstract}

Keywords: Groundwater quality, rock-water interaction, anthropogenic sources, upper wainganga river basin

\section{Introduction}

Water is the most important natural resources without which life would be non- existent. Freshwater quality and availability remain one of the most critical environmental and sustainability issues of the twenty-first century [1]. Of all sources of freshwater on the earth, groundwater constitutes over $90 \%$ of the world's readily available freshwater resources [2] with remaining $10 \%$ in lakes, reservoirs, rivers and wetlands. Groundwater is also widely used as a source, for drinking water supply and irrigation in food production [3]. However, groundwater is not only a valuable resource for water supply, but also a vital component of the global water cycle and the environment. Chemical and physical parameters of groundwater play an important role in assessing water quality. Groundwater quality as one of the most important aspects in water resource studies is largely controlled by discharge and recharges pattern, nature of host and associated rocks, and contaminated activities [4]. Weathering of minerals within the rocks is an important source of dissolved ions in groundwater $[5,6,7,8]$. Hydro-chemical assessment of groundwater system is based on groundwater chemistry, which, in turn, depends on a number of factors, such as geology, degree of chemical weathering of various rock types, quality of recharge water, and inputs from various sources other than water-rock interaction $[9,10]$.

As demand for groundwater has increased many folds in Maharashtra, it causes not only depletion of water levels, but also deterioration of water quality which results in increased use of groundwater for drinking and irrigation purposes. Little is known about the natural geochemical processes governing the chemical composition of the groundwater or the anthropogenic factors currently affecting it or is being degraded and to what extent in Gondia area. Few papers were published on groundwater quality in this part of Maharashtra state $[11,12,13,14]$. Thus, the assessment of quality of groundwater is mandatory to improve health conditions as well as to increase food productions. The focus of the present study is, 
therefore, on potability of groundwater from watershed of Gondia district, Maharashtra. An attempt is also made to obtain the nature and extent of fluoride contamination in groundwater.

\section{Study Area}

The Gondia district is situated on north-eastern side of Maharashtra State and share the state borders with Madhya Pradesh on north and Chhattisgarh in east (Fig. 1). It covers an area of about $5859 \mathrm{sq.km}$ and lies between $20^{\circ} 39$ and $21^{\circ} 38$ north latitudes and $79^{\circ} 52^{\prime}$ to $80^{\circ} 42$ east longitudes. The district falls under the Wainganga basin with rivers like Bagh, Chulbandh, Gadhavi and Bavanthadi being the tributaries of river Wainganga. The Gondia district is characterized by a hot arid climate. The normal annual rainfall over the district ranges from $1300 \mathrm{~mm}$ to $1500 \mathrm{~mm}$.

Geologically, major part of the district is occupied by the crystalline rocks of Pre-Cambrian formations that are Archaean. A map depicting the geological features is shown in Fig 2. The Archeans are represented by Amgaon Group consisting of Augen Gneisses, Amphibolites, Pegmatite and these formations are confined to the N \& NE corner of the district around Amgaon. The Amgaon group is followed by Dharwars (Lower Precambrian) which are represented by Sakoli Group of rocks; the latter forms the major stratigraphic unit in the district. The Sakoli Group consists of Quartzites, Schists, Phyllites, Metavolcanics and BIF and is confined to the NW and SW part of distric. The areas surrounding Salekasa, Wadegaon, Murdoli, Deori and Chinchgarh rocks consisting of Rhyolites, Andesites, and basic volcanics are present which respectively represents Bijli, Pitepani and Sitagota formations of the Dongargarh Group. The Wainganga valley forms a central depression in the district occupying half of its area. The valley floor is formed over Achaean crystalline terrain and is covered by riverine alluvium.

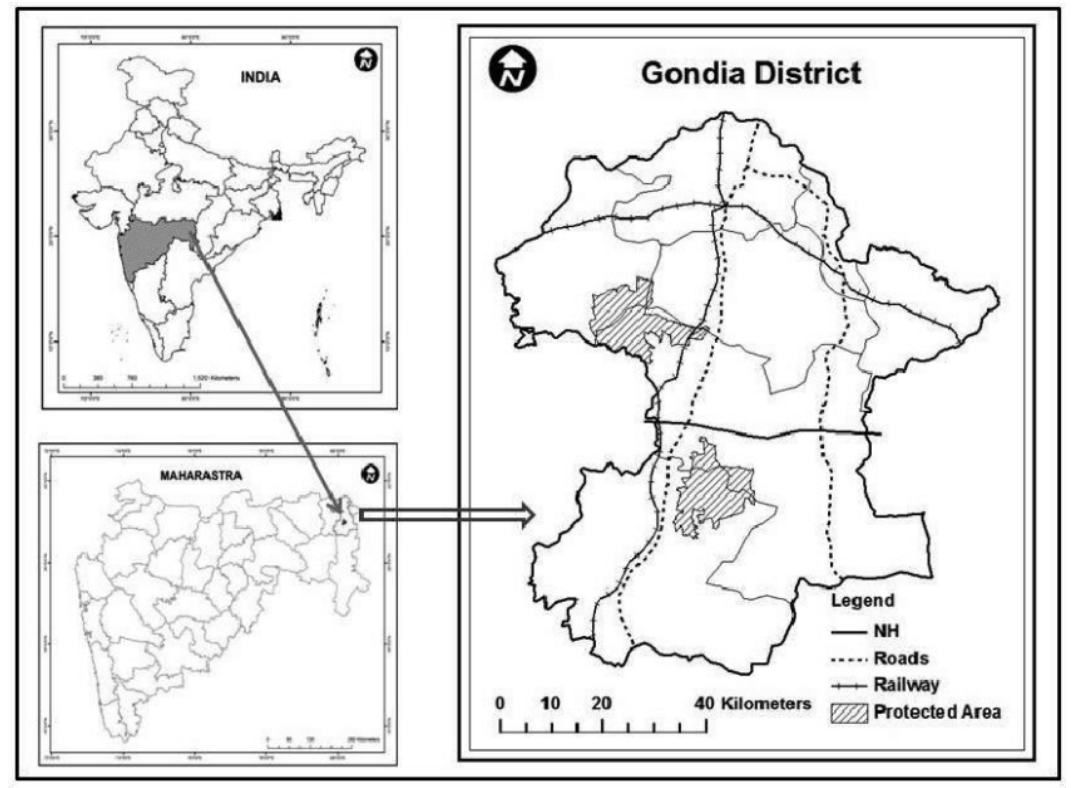

Figure 1. Location map of Gondia district

\section{$3 \quad$ Methodology}

In order to study the quality of groundwater, 64 groundwater samples were collected from shallow aquifer (DW) and deep aquifer (BW) from the study area during pre-monsoon season. They were determined for $\mathrm{pH}$, electrical conductivity (EC), total dissolved solids (TDS), total alkalinity (TA) as $\mathrm{CaCO}_{3}$, total hardness $(\mathrm{TH})$ as $\mathrm{CaCO}_{3}$, calcium $\left(\mathrm{Ca}^{2+}\right)$, magnesium $\left(\mathrm{Mg}^{2+}\right)$, sodium $\left(\mathrm{Na}^{+}\right)$, potassium $\left(\mathrm{K}^{+}\right)$, bicarbonate $\left(\mathrm{HCO}_{3}^{-}\right)$, carbonate $\left(\mathrm{CO}_{3}{ }^{2-}\right)$, chloride $\left(\mathrm{Cl}^{-}\right)$, sulphate $\left(\mathrm{SO}_{4}{ }^{2-}\right)$, nitrate $\left(\mathrm{NO}_{3}{ }^{-}\right)$and fluoride 
$\left(\mathrm{F}^{-}\right)$, following the standard water quality procedures [15]. Analyzed groundwater samples show that the value of computed ionic balance error (Eq. 1) is within the acceptable limit of $\pm 5 \%$.

$$
\% \text { Error }=(T C C-T C A) /(T C C+T C A) \times 100
$$

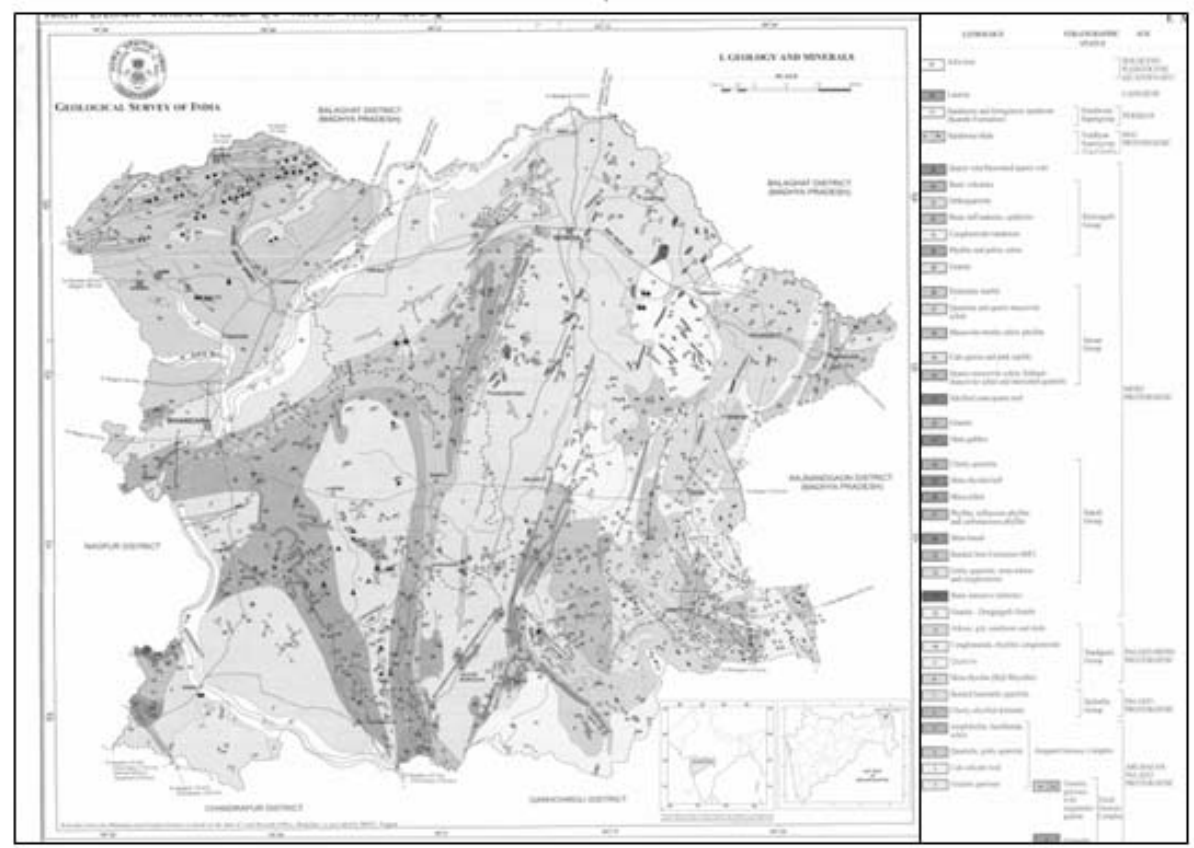

Figure 2. Geological map of Gondia district

Table 1. Stastical data of the groundwater samples ${ }^{a}$

\begin{tabular}{l|l|l|l|l}
\hline & \multicolumn{1}{|c|}{ Min } & \multicolumn{1}{|c|}{ Max } & Average & Standard Deviation \\
\hline $\mathrm{pH}$ & 6.60 & 8.10 & 7.10 & 0.27 \\
\hline $\mathrm{EC}$ & 490.00 & 3152.00 & 1292.63 & 480.96 \\
\hline $\mathrm{TDS}$ & 240.77 & 2184.50 & 818.78 & 366.00 \\
\hline $\mathrm{TA}$ & 105.00 & 539.34 & 253.32 & 90.46 \\
\hline $\mathrm{TH}$ & 30.00 & 689.00 & 395.00 & 144.32 \\
\hline $\mathrm{Na}^{+}$ & 7.40 & 278.00 & 113.93 & 77.97 \\
\hline $\mathrm{K}^{+}$ & 0.20 & 413.00 & 47.12 & 70.77 \\
\hline $\mathrm{Ca}^{2+}$ & 10.00 & 245.00 & 89.72 & 49.76 \\
\hline $\mathrm{Mg}^{2+}$ & 1.22 & 115.79 & 41.48 & 25.90 \\
\hline $\mathrm{HCO}_{3}{ }^{-}$ & 128.10 & 658.00 & 309.05 & 110.36 \\
\hline $\mathrm{Cl}^{-}$ & 17.75 & 543.00 & 157.48 & 101.09 \\
\hline $\mathrm{SO}_{4}^{2-}$ & 5.90 & 485.00 & 115.34 & 90.60 \\
\hline $\mathrm{NO}^{2-}$ & 1.61 & 285.00 & 98.35 & 75.98 \\
\hline $\mathrm{F}^{-}$ & 0.00 & 2.10 & 0.84 & 0.59 \\
\hline
\end{tabular}

${ }^{a} \mathrm{EC}$ is in $\mu \mathrm{S} / \mathrm{cm}$ at $25 \circ \mathrm{C}$ and other parameters are in $\mathrm{mg} / \mathrm{L}$ expect $\mathrm{pH}$ 


\section{Results and Discussion}

The analysed data of the groundwater samples collected from the study area is given in Table 1 . We referred the standard ranges for different hydro-chemical parameters of drinking water prescribed by WHO [16] and BIS [17] (Table2).

\section{1 pH, Electrical Conductivity, Total Dissolved Salts and Total Hardness}

The $\mathrm{pH}$ indicates the strength of the water to react with the acidic or alkaline material present in the water. This is caused by the influx of carbonates in the groundwater aquifer due to percolation of water through soil cover. The $\mathrm{pH}$ in the groundwater varied from 6.6 to 8.1, indicating an alkaline condition of groundwater. The $\mathrm{pH}$ values of all the collected samples are well within the safe limit as prescribed by WHO [16] and BIS [17]. Though $\mathrm{pH}$ has no direct effect on human health, but it shows close relations with some other chemical constituents of water [18].

Electrical conductivity (EC) values signify the amount of total dissolved salts, which in turn indicates the inorganic pollution load of water. Large variations in EC values have been observed in the study area (490 to $3152 \mu \mathrm{S} / \mathrm{cm}$ ) which reflect privilege of geochemical processes in an area. Sanchez-Perez and Tremolieres [19] suggested that the higher EC of the water is the result of ion exchange and solubilization in the aquifer. Thus, the EC can be classified as type I, if the enrichments of salts are low $(\mathrm{EC}<1,500 \mu \mathrm{S} / \mathrm{cm})$; type II, if the enrichment of salts are medium (EC: 1,500 and 3,000 $\mu \mathrm{S} / \mathrm{cm}$ ); and type III, if the enrichments of salts are high $(\mathrm{EC}>1,500 \mu \mathrm{S} / \mathrm{cm})$. According to the classification of EC, $70.3 \%$ of the total groundwater samples come under the type I (low enrichment of salts), $28.1 \%$ under the type II (medium enrichment of salts), and only one sample of Goda Tola village under the type III (high enrichment of salts).

Table 2. Standard ranges for hydro-chemical parameters for drinking water prescribed by WHO [16] and BIS [17]

\begin{tabular}{c|c|c|c|c|c}
\hline \multirow{2}{*}{$\begin{array}{c}\text { So } \\
\text { No }\end{array}$} & $\begin{array}{c}\text { Physiochemical } \\
\text { parameters }\end{array}$ & \multicolumn{2}{|c|}{ BIS (2003) } & \multicolumn{2}{c}{ WHO (2004) } \\
\cline { 3 - 6 } & Lesimit & $\begin{array}{c}\text { Permissible } \\
\text { Limit }\end{array}$ & $\begin{array}{c}\text { Desirable } \\
\text { Limit }\end{array}$ & $\begin{array}{c}\text { Permissible } \\
\text { Limit }\end{array}$ \\
\hline 1 & $\mathrm{pH}$ & $6.5-8.5$ & -- & $6.5-8.5$ & -- \\
\hline 2 & $\mathrm{EC}$ & -- & -- & -- & 1500 \\
\hline 3 & $\mathrm{TDS}$ & 500 & 2000 & 500 & 500 \\
\hline 4 & $\mathrm{TH}$ & 300 & 600 & 100 & 200 \\
\hline 5 & $\mathrm{TA}$ & -- & -- & & 150 \\
\hline 6 & $\mathrm{Ca}^{2+}$ & 75 & 200 & 50 & 200 \\
\hline 7 & $\mathrm{Mg}^{2+}$ & 30 & 100 & -- & -- \\
\hline 8 & $\mathrm{Na}^{+}$ & -- & -- & -- & - \\
\hline 9 & $\mathrm{~K}^{+}$ & -- & -- & -- & 600 \\
\hline 10 & $\mathrm{HCO}_{3}^{-}$ & -- & -- & 200 & 400 \\
\hline 11 & $\mathrm{Cl}^{-}$ & 250 & 1000 & 200 & 45 \\
\hline 12 & $\mathrm{SO}_{4}^{2-}$ & 200 & 400 & -- & 1.5 \\
\hline 13 & $\mathrm{NO}_{3}^{-}$ & -- & 45 & 0.6 & \\
\hline 14 & $\mathrm{~F}^{-}$ & 0.6 & 1.5 & & \\
\hline
\end{tabular}

The TDS varies from 240.77 to 2184.5 , which indicates a variation of degree of water quality due to an entering of foreign matter into the groundwater system. The $75 \%$ of groundwater samples (Table 3 ) come under fresh water type, as the value of TDS in them is less than 1,000 mg/l. The TH ranges from 30 to $689 \mathrm{mg} / \mathrm{l}$, because of the alkaline earths $\left(\mathrm{Ca}^{2+}\right.$ and $\left.\mathrm{Mg}^{2+}\right)$ of weak acids $\left(\mathrm{HCO}_{3}{ }^{-}\right.$and $\left.\mathrm{CO}_{3}{ }^{2-}\right)$ and strong acids $\left(\mathrm{Cl}^{-}, \mathrm{SO}_{4}{ }^{2-}\right.$ and $\left.\mathrm{NO}_{3}{ }^{-}\right)$. According to the $\mathrm{TH}$ classification [20], about $44 \%$ of the total groundwater samples fall in the category of hard $(150-300 \mathrm{mg} / \mathrm{l})$ and the rest of the water samples $(56 \%)$ in the category of very hard $([300 \mathrm{mg} / \mathrm{l})$. Based on $\mathrm{TH}$, Dufor and Becker [21] classified water as 0-60, 
soft; $61-120$, moderately hard; 121-180, hard and >180 very hard water. About $93.8 \%$ of samples belong to very hard type and the rest to hard type water.

\subsection{Calcium, Magnesium, Sodium and Potassium}

The order of cationic abundances is, thus, $\mathrm{Na}^{+}>\mathrm{Ca}^{2+}>\mathrm{K}^{+}>\mathrm{Mg}^{2+}$. Calcium ranged between 10 and $245 \mathrm{mg} / \mathrm{L}$. Only two samples have $\mathrm{Ca}^{2+}$ concentration above Permissible limit suggested by WHO and BIS $[16,17]$. Its behaviour in natural aqueous systems is generally governed by the availability of the more soluble calcium compounds and by solution-gas phase equilibrium that involve carbon dioxide species, or by the availability of sulfur in the form of sulfate [22]. Further, it is observed that the calcium concentrations are low compared to other cations such as sodium in these groundwaters. The reaction of calcium with sulfates and subsequent precipitation decreases the concentration of calcium and sulfates ions in the groundwater [23]. The Mg concentrations varied between 1.2 and $115.79 \mathrm{mg} / \mathrm{L}$. The cation-exchange behaviour of magnesium is similar to that of calcium. Both ions are strongly adsorbed by clay minerals and other surfaces having exchange sites. Dissolved magnesium exceeds calcium in water once calcium precipitates after reaching super saturation and accounts for higher magnesium concentrations than calcium [22].

The $\mathrm{Na}^{+}$concentrations are ranging between 7.4 and $278 \mathrm{mg} / \mathrm{L}$. Potassium concentrations are varying between 0.2 and $413 \mathrm{mg} / \mathrm{L}$. The concentration of $\mathrm{Na}^{+}$(Average $113.93 \mathrm{mg} / \mathrm{L}$ ) is higher than that of $\mathrm{K}^{+}$ (Average $47.12 \mathrm{mg} / \mathrm{L}$; Table 1). The higher concentration of Na+ among the cationic concentrations reflects a rock weathering and/or dissolution of soil salts stored by the influence of evaporation [24] and also indicates its higher solubility behaviour, while the lower concentration of $\mathrm{K}^{+}$is because of its fixation on clay minerals [22]. Another point is that the concentration of $\mathrm{Na}^{+}$is greater than that of $\mathrm{Ca}^{2+}$ (Average $89.72 \mathrm{mg} / \mathrm{L}$ ). This is expected by the process of ion exchange between $\mathrm{Na}+$ and $\mathrm{Ca}^{2+}$ and/or the formation of kankar (precipitation of $\mathrm{CaCO}_{3}$ ) in the soil zone.

\subsection{Total Alkalinity, Bicarbonates, Chlorides and Sulphate}

In the groundwater samples of study area, $\mathrm{HCO}_{3}{ }^{-}$is the dominant anion followed by $\mathrm{Cl}^{-}, \mathrm{SO}_{4}{ }^{2-}$ and $\mathrm{NO}_{3}{ }^{-}$. The TA is between 105 and $539.34 \mathrm{mg} / \mathrm{L}$ (Table 1). This is due to the $\mathrm{HCO}_{3}{ }^{-}$ion only, as the $\mathrm{pH}$ less than 8.6. The concentration of bicarbonates varies between 128 and $658 \mathrm{mg} / \mathrm{L}$. The higher content of bicarbonates indicates an intense weathering of rocks, which favors an active mineral dissolution [25, 26]. The excess of $\mathrm{Cl}^{-}$in the water is usually taken as an index of pollution and considered as tracer for groundwater contamination [26]. It varies from 17.75 to $543 \mathrm{mg} / \mathrm{L}$ in groundwater of study area. The permissible limit of $\mathrm{Cl}^{-}$in potable water is $250 \mathrm{mg} / \mathrm{L}$, which may be further relaxed up to $1,000 \mathrm{mg} / \mathrm{L}$ for Indian conditions [17]. $12.5 \%$ of samples have $\mathrm{Cl}^{-}$concentration above the desirable limit. $\mathrm{SO}_{4}{ }^{2-}$ varies from 5.9 to $489 \mathrm{mg} / \mathrm{L}$. At higher concentration, $\mathrm{SO}_{4}{ }^{2-}$ may cause gastro-intestinal irritation particularly when $\mathrm{Mg}^{2+}$ and $\mathrm{Na}^{+}$are also present in drinking water resources.

\subsection{Nitrates and Fluorides}

Nitrogenous materials are rare in the geological record; therefore, occurrence of nitrate in groundwater is normally of anthropogenic nature. In study area, the $\mathrm{NO}_{3}{ }^{-}$concentration varies from traces to $285 \mathrm{mg} / \mathrm{l}$ in groundwater. About $70.4 \%$ of water samples have $\mathrm{NO}_{3}{ }^{-}$concentration above the tolerance limit of 45 $\mathrm{mg} / \mathrm{L}$ [16, 17] (Table 1, 2). Fluoride $\left(\mathrm{F}^{-}\right)$is essential for normal bone growth, but its higher concentration in the drinking water poses great health problems. The WHO's recommendation has placed an upper limit at $1.50 \mathrm{mg} / \mathrm{L}$ for $\mathrm{F}^{-}$in the potable water. In the groundwater of study area, $\mathrm{F}^{-}$ concentration is found to be in the range from traces to $2.1 \mathrm{mg} / \mathrm{L}$.

\subsection{Origin of Solutes}

The relationship between $\mathrm{Na}^{+}$and $\mathrm{Cl}^{-}$has often been used to identify the mechanisms for acquiring salinity in semi-arid regions $[27,28,29]$. The analytical data of groundwater samples of both seasons are plotted between $\mathrm{Na}^{+} \& \mathrm{Cl}^{-}$(Fig. 3). The Na-Cl plot deviates from the expected 1:1 relation. This plot infers that the groundwater has an excess concentration of $\mathrm{Na}^{+}$which might be derived from the silicate 
weathering [30] and other sources also. If it is so, the groundwater would have $\mathrm{HCO}_{3}^{-}$as the most dominant anion [31], as observed in the study area. The chemical data of the groundwater sampling points of the study area are plotted in $\mathrm{Ca}^{2+}+\mathrm{Mg}^{2+}$ versus $\mathrm{HCO}_{3}^{-}$diagram (Fig. 4), where sampling points do not fall below the equiline $\left(\mathrm{Ca}^{2+}+\mathrm{Mg}^{2+}: \mathrm{HCO}_{3}^{-}=1\right)$, which indicates that an excess of alkalinity has not been balanced by alkalies $\left(\mathrm{Na}^{+}\right.$and $\left.\mathrm{K}^{+}\right)$and supports the anthropogenic source with the weathering of the rocks. The increase of alkalies $\left(\mathrm{Na}^{+}+\mathrm{K}^{+}\right)$with an increase of $\mathrm{Cl}^{-}+\mathrm{SO}_{4}{ }^{2-}$ is not uniformly spread in dugwell and bore well samples of both seasons (Fig. 5), because the contribution of dissolved salts is from the source of anthropogenic origin (agricultural activities and improper drainage conditions). The strong correlation exists between TDS and $\mathrm{Na}^{+}(\mathrm{r}=0.7361)$, $\mathrm{TDS}_{-} \mathrm{Ca}^{2+}(\mathrm{r}=0.6625)$, $\mathrm{TDS}_{-N_{3}}{ }^{-}(\mathrm{r}=0.7535), \mathrm{TDS}_{-} \mathrm{SO}_{4}{ }^{2-}(\mathrm{r}=0.747)$ and $\mathrm{TDS}_{-} \mathrm{Cl}^{-}(\mathrm{r}=0.8333)$ which supports the anthropogenic input of mainly domestic and industrial waste for these ions in ground water [32].

Table 3. Groundwater classification based on TDS

\begin{tabular}{l|l|l|l}
\hline DS $(\mathbf{m g} / \mathbf{L})$ & Classification & $\begin{array}{l}\text { No. of } \\
\text { Samples }\end{array}$ & $\%$ \\
\hline & & & \\
\hline & & & \\
\hline $10,000-100,000$ & Saline water type & 0 & 0 \\
\hline$>100,000$ & Brine water & 0 & 0 \\
\hline Total & & 64 & 100 \\
\hline
\end{tabular}

Table 4. Groundwater classification based on $\mathrm{TH}$

\begin{tabular}{l|l|l|l}
\hline TH $(\mathbf{m g} / \mathbf{L})$ & Classification & $\begin{array}{l}\text { No. of } \\
\text { Samples }\end{array}$ & $\mathbf{\%}$ \\
\hline $121-180$ & Hard & 1 & 1.6 \\
\hline$>180$ & Very Hard & 60 & 93.8 \\
\hline Total & & 64 & 100 \\
\hline
\end{tabular}

Alkalinity of the circulating water is mainly responsible for the high incidence of fluoride. The longer residence time of water in the aquifer zone, caused by a high rate of evapotranspiration and a weathered zone of low hydraulic conductivity, are the supplementary factors that activate the dissolution of fluorine-bearing minerals to further increase $\mathrm{F}^{-}$content in the groundwater. Higher alkalinity of groundwater activates the leaching of fluoride and thus affects the concentration of fluoride in the groundwater $[33,34]$. Fluoride shows a negative correlation with $\mathrm{Ca}^{2+}(\mathrm{r}=-0.221)$ and $\mathrm{HCO}_{3}{ }^{-}$. Even Fluoride shows a positive correlation with $\mathrm{Na}^{+}(\mathrm{r}=0.275,0.3207)$ and with $\mathrm{pH}(\mathrm{r}=0.18)$ in the groundwater samples analysed in the study area (Figs. 6, 7, and 8). From natural sources, a considerable amount of fluoride may be contributed through anthropogenic activities. Phosphatic fertilizers, which are extensively used in agriculture, often contain fluoride as an impurity that can leach down to the saturated zone. In post monsoon season, the correlation between $\mathrm{Ca}^{2+}$ and $\mathrm{F}^{-}$is positive which is due to recharging of aquifer by rain water. Thus, the ranges of such ionic species may suggest favourable chemical conditions for the fluoride dissolution process in the study area.

\section{Conclusion}

The results of major ion chemistry in the study area show enrichment of sodium, calcium, and magnesium among cations and bicarbonate and chlorides among anions. The study reveals that 93.6\% samples from study area are found to be very hard type. About $70.4 \%$ of aquifer waters have $\mathrm{NO}_{3}^{-}$ concentration above the tolerance limit of $45 \mathrm{mg} / \mathrm{l}$ and not suitable for drinking. Our studies found that the silicate weathering and anthropogenic activities are the main controlling processes in the variation of groundwater quality, which is supported by the $\mathrm{Na}^{+} / \mathrm{Cl}^{-}$plot. The relations also suggest that the ion exchange and evaporation are the secondary processes for higher concentrations of $\mathrm{Na}^{+}$and $\mathrm{Cl}^{-}$ions. 


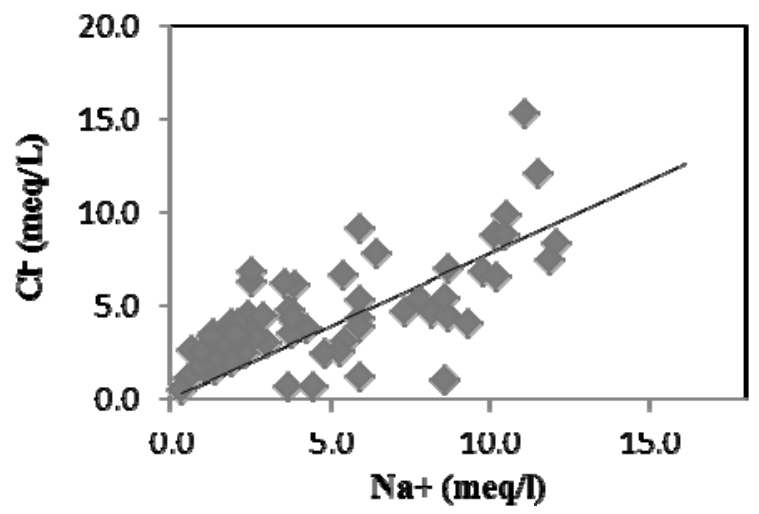

Figure 3. Inter ionic plot between $\mathrm{Na}+\& \mathrm{Cl}-$

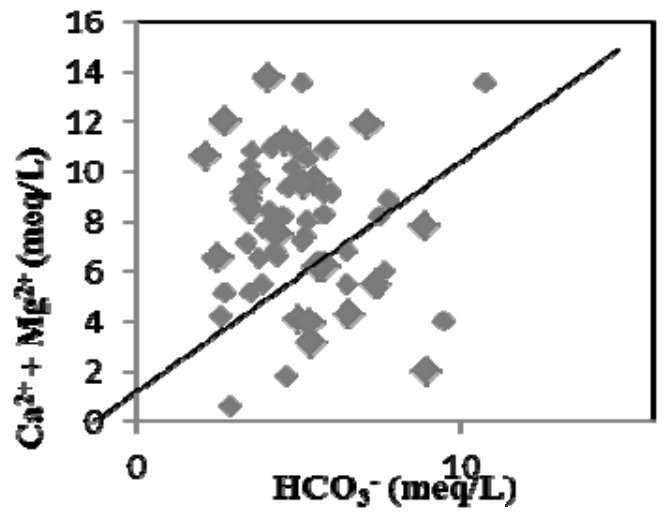

Figure 4. Inter ionic plot of $\mathrm{Ca} 2++\mathrm{Mg} 2+$ versus $\mathrm{HCO} 3-$ diagram

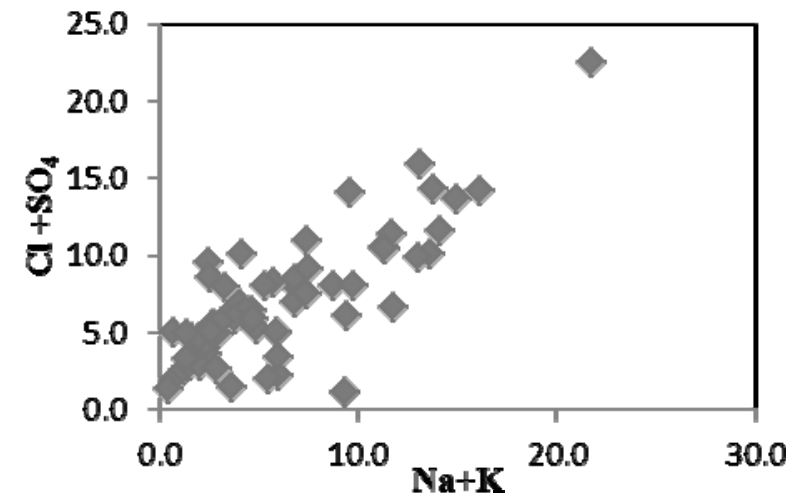

Figure 5. Inter ionic plot of $(\mathrm{Na}++\mathrm{K}+)$ versus $(\mathrm{Cl}-+\mathrm{SO} 42-)$

The influences of agricultural fertilizers and poor drainage conditions are the other reasons for increasing $\mathrm{Mg}^{2+}, \mathrm{Na}^{+}, \mathrm{Cl}^{-}, \mathrm{SO}_{4}{ }^{2-}$ and $\mathrm{NO}_{3}{ }^{-}$ions in the groundwater. Further, the excess alkaline condition in water acts more effectively to dissolve $\mathrm{F}^{-}$bearing minerals. The emphases on public awareness about the adverse effects to human health of high $\mathrm{F}^{-}$concentrations in drinking water and the educations on the mechanisms necessary to improve the health status of the population are essential. Greater intake of 
calcium and tamarind in the diet of the inhabitants of the endemic regions could alleviate the fluorosis problem to certain extent.

\section{References}

1. UNEP (United Nations Environment Programme). "Global Environment Outlook (GEO-3),"pp.416, 2002.

2. J.A .Boswinkel, "Information Note," International Groundwater Resources Assessment Centre (IGRAC), Netherlands Institute of Applied Geoscience, Netherlands, 2000.

3. I.S. Zekster and L.G. Everett, "Groundwater resources of the world and their use, IHP-VI," Series on Groundwater No. 6., UNESCO (United Nations Educational, Scientific and Cultural Organisation.

4. Subba Rao, "Fluoride in groundwater, Varaha River Basin, Visakhapatnam District, Andhra Pradesh, India," Environ Monit Assess,vol. 152, pp. 47-60, 2009.

5. G.Jacks, "Chemistry of groundwater in a district in Southern India," Journal of Hydrology, vol.18, pp.185-200, 1973.

6. S.K. Bartarya, "Hydrochemistry and rock weathering in a subtropical lesser Himalayan river basin in Kumaun, India," Journal of Hydrology, v.146, pp.149-174, 1993.

7. N. Subba Rao, J. Prakasa Rao, D. John, K. V. Srinivasa Rao, C. Krishna, and B. Nagamalleswara Rao, "Hydrogeochemistry and groundwater quality in a developing environment of a semi-arid region, Guntur, Andhra Pradesh," Journal of the Geological Society of India, vol. 59, pp.159-166, 2002.

8. J. Si, F.Qi, W. Xiaohu, S.Yonghong, X. Haiyang and C. Zongqiang, "Major ion chemistry of groundwater in the extreme arid region northwest China," Environmental Geology, vol.57, pp.1079-1087, 2009.

9. T. Ayenew, M. Demlie and S. Wohnlich, "Hydrogeological framework and occurrence of groundwater in the Ethiopian aquifers", J Afr Earth Sci, vol. 52, pp. 97-113, 2008.

10.L. Giridharan, T. Venugopal and M. Jayaprakash, "Identification and evaluation of hydrogeochemical processes on river Cooum, South India," Environ Monit Assess, vol. 162, pp. 277-289, 2010.

11.D. Marghade, D.B. Malpe and A.B. Zade, "Assessment of groundwater quality in landfill area of Nagpur city, central India," J Environ Hydrol, vol.18, paper 18, pp.1-12, 2010.

12.D. Marghade, D.B. Malpe and A.B. Zade, "Geochemical characterization of groundwater from northeastern part of Nagpur urban, Central India," Environ Earth Sci, vol. 62, pp. 1419-1430, 2011.

13.D. Pandey and M. M. Ali, "Water Quality Index Of The Wainganga River, Bhandara Maharashtra, India," International Journal of Civil, Structural, Environmental and Infrastructure Engineering Research and Development, Vol. 3, no. 2, pp. 115-124, 2013.

14.D. Pandey, Y.B. Katpatal, P. Kundal and V.R. Chandrayan, "Nitrate Contamination Indexing of Subsurface Water of Upper Wainganga Drainage Basin of India," International Journal of Innovative Research in Science, Engineering and Technology, Vol. 5, No. 1, 2016.

15.APHA, "Standard methods for the examination of water and wastewater" American Public Health Association Washington, pp. 326, 1992.

16.WHO, "Guidelines for drinking water quality," World Health Organization, Geneva, pp. 515, 2004.

17.BIS, "Drinking water specifications. Bureau of Indian Standards," IS 10500, 2003.

18.R. Pitt, S. Clark, and R. Field, "Groundwater contamination potential from storm water infiltration practices. Urban water," vol.1, pp.217-236, 1999.

19.J.M. Sanchez- Perez and M. Tremolieres, "Change in groundwater chemistry as a consequence of suppression of floods: The case of the Rhine floodplain," Journal of Hydrology, vol. 270, pp. 89-104, 2003.

20.C.N. Sawyer and McCarty P.L., "Chemistry for sanitary engineers," McGraw-Hill, New York, 2nd edn., 1967.

21.C.N. Dufor and E. Becker, "Public water supplies of the 100 largest cities in the US," US geological survey water supply, Paper No. 1812, pp.364, 1964

22.J. D. Hem, "Study and interpretation of chemical characteristics of natural water," USGS Water-Supply, Paper $2254,1991$.

23.A. Nagaraju, M. R. S. Sarma, J. A. Aitkenhead-Peterson and K. Sunil, "Fluoride incidence in groundwater: a case study from Talupula, Andhra Pradesh, India," Environ Monit Assess" 172, pp. 427-443, 2011.

24.R.E. Stallard and J.M. Edmond, "Geochemistry of Amazon River: the influence of the geology and weathering environment on the dissolved load," J Geophys Res, vol. 88, 9671-9688, 1983. 
25.W, Stumm and J.J. Morgan, "Aquatic chemistry," Wiley-Interscience, New York, 1996.

26.M. Loizidou and E.G. Kapetanios, "Effect of leachate from landfills on underground water quality," The Science of Total Environment, vol.128, pp.69-81, 1993.

27.M. Magaritz, A. Nadler, H. Koyumdjisky and N. Dan, "The use of Na/ Cl ratio to trace solute sources in a semiarid zone," Water Resour Res, vol. 17, pp. 602-608, 1981.

28.W. Dixon and B.Chiswell, "The use of hydrochemical sections to identify recharge areas and saline intrusions in alluvial aquifers, southeast Queensland, Australia," Journal of Hydrology, vol.130, pp.299-338, 1992.

29.K. Sam, "Recharge mechanisms and geochemical processes in a semi-arid sedimentary basin, Eastern cape, South Africa," Journal of Hydrology, vol.139, pp.27-48, 1992.

30.M. Meyback, "Global chemical weathering of surficial rocks estimated from river dissolved loads," Am J Sci, vol. 287, pp. 401-428, 1987.

31.R.J. Rogers, "Geochemical comparison of groundwater in areas of New England, New York and Pennsylvania," Ground Water, vol. 27, pp. 690-712, 1989.

32.M. Jalali, "Geochemistry characterisation of groundwater in an agricultural area of Razan, Hamadan, Iran," Environ Geol, vol. 56, pp. 1479-1488, 2009.

33.B. K. Wodeyar and G.Sreenivasan, "Occurrence of fluoride in the groundwaters and its impact in Peddavankahalla Basin, Bellary District, Karnataka, India-A preliminary study," Current Science, vol. 70, pp. $71-74,1996$

34.A. N. Tiwari, V. P, Nawale, J. A. Tambe and Y. Satya Kumar, "Correlation of fluoride with bicarbonate in groundwater of exploratory wells in parts of Maharashtra," Journal of Applied Geochemistry, vol. 10, pp. 93 $102,2008$. 